\title{
A Hazard Classification Method for Facilities Containing Toxic Chemicals at the Pacific Northwest Laboratory
}

G. E. Backman

J. T. Denovan

N. P. Nisick

J. A. Piatt

July 1986

Prepared for the U.S. Department of Energy under Contract DE-AC06-76RLO 1830

Pacific Northwest Laboratory

Operated for the U.S. Department of Energy

by Battelle Memorial Institute 


\title{
DISCLAIMER
}

This report was prepared as an account of work sponsored by an agency of the United States Government. Neither the United States Government nor any agency thereof, nor any of their employees, makes any warranty, express or implied, or assumes any legal liability or responsibility for the accuracy, completeness, or usefulness of any information, apparatus, product, or process disclosed, or represents that its use would not infringe privately owned rights. Reference herein to any specific commercial product, process, or service by trade name, trademark, manufacturer, or otherwise, does not necessarily constitute or imply its endorsement, recommendation, or favoring by the United States Government or any agency thereof. The views and opinions of authors expressed herein do not necessarily state or reflect those of the United States Government or any agency thereof.

\author{
PACIFIC NORTHWEST LABORATORY \\ operated by \\ BATTELLE \\ for the \\ UNITED STATES DEPARTMENT OF ENERGY \\ under Contract DE-AC06-76RLO 1830
}

\begin{tabular}{|c|c|}
\hline \multicolumn{2}{|c|}{ Printed in the United States of America } \\
\hline \multirow{2}{*}{\multicolumn{2}{|c|}{$\begin{array}{l}\text { Available from } \\
\text { National Technical Information Service }\end{array}$}} \\
\hline & \\
\hline \multicolumn{2}{|c|}{ United States Department of Commerce } \\
\hline \multicolumn{2}{|c|}{5285 Port Royal Road } \\
\hline \multicolumn{2}{|c|}{ Springfield, Virginia 22161} \\
\hline \multirow{2}{*}{\multicolumn{2}{|c|}{$\begin{array}{l}\text { NTIS Price Codes } \\
\text { Microfiche A01 }\end{array}$}} \\
\hline & \\
\hline \multicolumn{2}{|c|}{ Printed Copy } \\
\hline & Price \\
\hline Pages & Codes \\
\hline $001-025$ & $\mathrm{~A} 02$ \\
\hline $026-050$ & $\mathrm{A03}$ \\
\hline 051-075 & A04 \\
\hline 076-100 & A05 \\
\hline $107-125$ & A06 \\
\hline $126-150$ & $\mathrm{~A} 07$ \\
\hline $151-175$ & A08 \\
\hline $176-200$ & $A 09$ \\
\hline $201-225$ & A010 \\
\hline $226-250$ & A011 \\
\hline $251-275$ & A012 \\
\hline $276-300$ & $A 013$ \\
\hline
\end{tabular}


A HAZARD CLASSIFICATION

METHOD FOR FACILITIES

CDNTAINING TOXIC CHEMICALS

AT THE PACIFIC NORTHWEST

LABORATORY

G. E. Backman

J. T. Denovan

N. P. Nisick

J. A. Piatt

Ju1y 1986

Prepared for

the U.S. Department of Energy

under Contract DE-AC06-76RLO 1830

Pacific Northwest Laboratory

Richland, Washington 99352 


\section{SUMMARY}

This document presents guidance to management on how to proceed in determining if the quantity of nonradioactive toxic materials in any Pacific Northwest Laboratory (PNL) or PNL-managed facility constitutes a potential threat to the public or to employees outside the facility.

The "Immediately Dangerous to Life or Health" concept developed by the Department of Health, the Institute of Occupational Safety and Health, the Occupational Safety and Health Administration, and contractors who work with these organizations has been used as the measuring device to determine potential effects. The hazard classes (low, moderate and high) defined in the Department of Energy Order 5481.1A have been used to determine the seriousness of the potential effects.

The management requirements related to the hazard classification have also been included in the document. 
CONTENTS

SUMMARY...........................

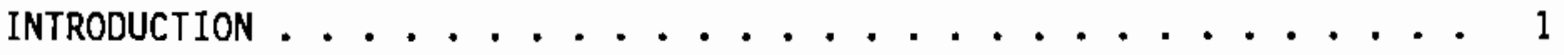

ENGINEERING AND ADMINISTRATIVE CONTROL MEASURES. . . . . . . . 3

HAZARD CLASSIFICATION METHOD .............. 5

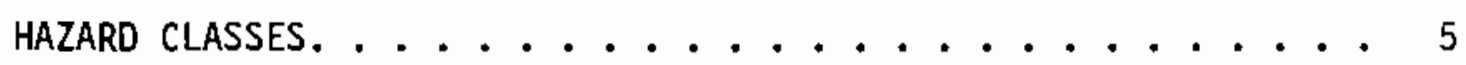

ASSUMPTIONS USED TO ESTABLISH RELEASE GUIDELINES . . . . . 7

DETERMINATION OF THE HAZARD CLASS ............ 8

PROCEDURE WHERE NO IDLH LIMITS HAVE BEEN ESTABLISHED . . . . . . 11

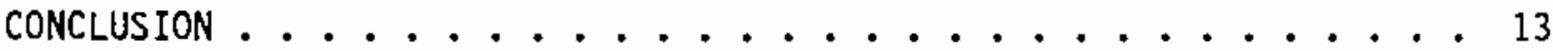

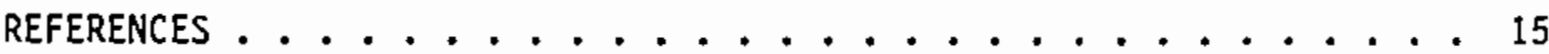




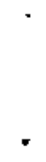




\section{INTRODUCTION}

Pacific Northwest Laboratory (PNL) ${ }^{(a)}$ is responsible for research and development programs assigned by the Richland Operations Office of the United States Department of Energy (DOE-RL). To meet this responsibility, PNL manages a number of nonnuclear and nonreactor nuclear facilities at the Hanford Site near Richland, Washington. These facilities may contain nonradioactive toxic materials that, if accidentally released to the environment, could affect the public or nearby employees.

The DOE Orders establish the ground rules that PNL follows for managing these facilities. DOE Order 5481.1A, "Safety Analysis and Review System," states: "It is the policy of DOE to assure that DOE Operations are conducted in a manner that will: 1) $11 \mathrm{mit}$ risks to the health and safety of the public and employees, and 2) adequately protect property and the environment. This assurance is provided, in part, by the preparation and review of safety analyses for DOE Operations" (DOE 1979).

The PNL safety program, which is coordinated by the Laboratory Safety Department, protects employees from undue risk while working with nonradioactive toxic materials; however, little guidance is avallable to evaluate the effects of toxic material releases on the public and nearby employees in the event of an accident. The General Safety Assessment Document for PNL-Managed Nonreactor Nuclear Facilities (GSAD) (Backman et al. 1981) provides the criteria or basis for determining the level of safety evaluation required for nonreactor nuclear facilities. While the GSAD defines the hazard levels for potential radioactive releases, it does not define the hazard levels for nonradiological materials.

The purpose of this document is to present a method for assessing the potential hazards to the public and to the employees near the facility from nonradioactive toxic materials contained in any PNL-managed facility. Facilities management, in conjunction with Laboratory Safety personnel, can use this hazard classification method (described in detall in this document) as a basis for actions needed to protect employees and the public. This document,

(a) PNL is operated by Battelle Memorial Institute for the U. S. Department of Energy. 
in conjunction with the GSAD, also represents guidance on when safety documentation is required for a facility. 


\section{ENGINEERING AND ADMINISTRATIVE CONTROL MEASURES}

Engineered safety features and administrative controls are in place at PNL to prevent or mitigate releases of nonradioactive toxic materials to the environs. However, a conservative approach was used to develop the chemical hazard classes for this document, and thus no credit was given for these features or controls when evaluating the consequences of a release.

Each facility's operation is conducted in accordance with various design, operational, and administrative documents, which establish formal programs to ensure compliance with applicable DOE and other federal requirements. When necessary, instructions and procedures are prepared to transiate the general requirements of DOE and PNL directives into specific guidance and limits to be observed by the operating staff.

Engineered safety features include facility designs that preclude or minimize the release of a chemical contaminant beyond the building structure. When a safety evaluation is required, a detailed study of the adequacy of the engineered safety features used to minimize potential releases of toxic chemicals is an essential part of the evaluation.

The administrative controls in place at PNL ensure a high degree of safety to the public and employees. These controls are administered through instructions stated in a series of manuals that are based on the safety requirements set forth in the Management Guide for Battelle's Pacific Northwest Division. A more detailed description of the PNL administrative control measures is contained in the GSAD. 


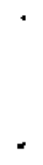




\section{HAZARD CLASSIFICATION METHOD}

The hazard classification method at PNL is based on a determination of the consequences to the public and nearby employees from accidental releases of nonradioactive toxic materials.

The criteria established for the hazard classification method were based upon the concept of "Immediately Dangerous to Life or Health" (IDLH) ${ }^{\text {(a) }}$ concentrations. The IDLH is the maximum concentration level from which an individual could escape within 30 minutes without any escape-impairing symptoms or irreversible health effects. IDLH levels have been developed for many substances, including most of the widely used chemicals. These levels were established through the cooperative efforts of the Department of Labor, the National Institute of Occupational Safety and Health (NIOSH), the Occupational Safety and Health Administration (OSHA), and the contractors who work with these organizations. There are substances, however, for which the IDLH levels have not been established. The recommended procedures for handling these substances are discussed in the next section.

\section{HAZARD CLASSES}

The hazard classes, as suggested in DOE Order 5481.1A, Chapter II, are defined as follows:

- low--hazards with the potential for minor onsite and negligible offsite impacts to people or the environment

- moderate--hazards with the potential for considerable onsite impacts to people or the environment but, at most, minor offsite impacts

- high--hazards with the potential for major onsite or offsite impacts to people or the environment.

(a) The IDLHs for many nonnuclear chemicals are listed in the NIOSH/OSHA Pocket Guide to chemical Hazards. (Makinson, Stricoff, and Partidge 1978.) 
The hazard classes are expressed in terms of IDLH and selected with close attention given to the definitions stated in DOE Order 5481.1A, Chapter II (see Table 1).

The PNL method for classifying chemical hazards in facilities is designed to identify those PNL-managed facilities that belong in the moderate- and highhazard classes. For these facilities, a Safety Evaluation Document (SED) is prepared to determine the potential IDLH exposures to individuals located outside each facility under worst-case accident scenarios. If the SED demonstrates that the resulting IDLH exposures to individuals located outside the facility are within the low-hazard class because of the location or manner of use of the toxic materials within the facility, the SED is the only safety analysis documentation required.

If a facility falls in the moderate- or high-hazard class as a result of the SED analysis, the nonnuclear chemical inventory must be reduced until the facility falls in the low-hazard class, or a Safety Analysis Report (SAR) must be prepared to show that sufficient administrative and engineering controls are in place to operate the facility without undue risk. Hazard classes are used to assess potential releases so that the company can be assured that appropriate controls are established.

As a result of this classification method, PNL should have sufficient control over all PNL-managed facilities so that neither employees nor the public will be exposed to hazardous quantities of toxic materials.

IABLE 1. Hazard Classes for Nonnuclear Chemicals (a)

$\frac{\text { Hazard Class }}{\text { Low }}$

Moderate

High

$\frac{\text { For Public }}{<10 \% \text { of IDLH }}$
$10 \%$ to $100 \%$ IDLH
$>100 \%$ IDLH

\begin{tabular}{l} 
For Employees \\
\hline $100 \%$ of IDLH \\
$100 \%$ to $1000 \%$ IDLH \\
$>1000 \%$ IDLH
\end{tabular}

$\frac{\text { For Employees }}{\langle 100 \% \text { of IDLH }}$

$>1000 \%$ IDLH

(a) These classes have been established for evaluation purposes only. They are not intended to indicate that employees or the public would actualiy be exposed to these levels. 


\section{ASSUMPTIONS USED TO ESTABLISH RELEASE GUIDELINES}

The assumptions used to establish the guidelines for PNL facility hazard classification of industrial chemical hazards follow, where possible, the guidelines of the GSAD for PNL-managed nonreactor nuclear facilities. These assumptions include:

- The release height is 10 meters and represents the height of a typical gaseous-effluent-release point on a 300 Area building. (a)

- The time-integrated dispersion coefficient is $4.8 \times 10^{-3} \mathrm{sec} / \mathrm{m}^{3}$ for the maximum-exposure locations onsite.

- The time-integrated dispersion coefficient is $4.7 \times 10^{-4} \mathrm{sec} / \mathrm{m}^{3}$ for the maximum-exposure location at the site boundary (i.e., maximum exposure to a member of the public).

NOTE: These two dispersion coefficients are conservatively based on adverse meteorological conditions using the models described in the Final Environmental Statement: Waste Management Operations, Hanford Reservation, Richland, washington (ERDA 1975). The onsite coefficient for a location 100 meters downind of the release point is used to calculate the onsite toxic material exposures. The site boundary coefficient assumes as average distance to the site boundary of $\mathbf{8 0 0}$ meters. The coefficients are used to calculate toxic material exposure to nearby employees and members of the public.

- For particulates, $0.1 \%$ of the inventory at a work site is released. NOTE: This assumption is based upon research by Mishima and Schwendiman (1972) involving release of $\mathrm{UO}_{2}$ powder during a fire and neglects the cleanup attributed to any building's exhaust filtration. This assumption could be applied to other sources.

(a) The Hanford Site is divided into numbered areas such as the 100, 200, and 300 Areas. 
Further assumptions that were used to determine the extent of accidental releases include:

- For lithium, sodium, or potassium, when stored as metals, $40 \%$ would be released in the form of hydroxides (Atomics International 1970).

- For gases, organics, and acids with boiling points below $100^{\circ} \mathrm{C}, 100 \%$ would be released.

- For organics and acids with bolling points above $100^{\circ} \mathrm{C}, 10 \%$ would be released.

NOTE: The values of releases for organics and acids were arbitrarity chosen and are quite conservative. Other temperatures were considered for the break point between a $100 \%$ release and a lesser release. The Department of Transportation's definition of flammable liquid temperature, $30^{\circ} \mathrm{C}$, and the Environmental Protection Agency's definition of ignitable 1 fquid temperature, $60^{\circ} \mathrm{C}$, were considered but were discarded for the more conservative value.

- For elemental iodine, $25 \%$ would be released as $I_{2}$.

- For mercury, $10 \%$ would be released.

- The release time would be over a 30-minute period.

DETERMINATION OF THE HAZARD CLASS

The hazard classification for a facility can be determined by using the following formula:

$$
H=c \sum \sum \frac{A_{i} Q_{i}}{(I O L H)_{j}}
$$

where $A_{f}=$ the postulated percentage release for the $i$ th material $Q_{j}=$ quantity in grams of the $i$ th material in the facility

$(\text { IDLH })_{j}=$ the IDLH of the $i$ th material

$C=a$ constant equal to $\frac{1}{3.8 \times 10^{5}}$ based on the dispersion assumptions

$H=$ the hazard classification (if $\mathrm{H}\langle 1$, the hazard class is "low": 1 to 10 , the hazard class is "moderate"; $>10$, the hazard class is "high") 
An example using the formula for classifying chemical hazards in a facility is presented in the following paragraphs.

The inventory of toxic substances in a facility is shown below with the IDLH and the postulated release.

\begin{tabular}{|c|c|c|c|}
\hline Substance & $\underline{I D L H}, \mathrm{mg} / \mathrm{m}^{3}$ & Release, \% & Inventory, $\mathrm{g}$ \\
\hline A & 0.3 & 100 & 2,000 \\
\hline B & 0.6 & 100 & 4,000 \\
\hline c & 0.8 & 100 & 3,000 \\
\hline D & 7.5 & 10 & 10,000 \\
\hline$E$ & 8.0 & 10 & 5,100 \\
\hline $\mathbf{F}$ & 9.0 & 10 & 7,500 \\
\hline G & 0.1 & 0.1 & 5,000 \\
\hline $\mathrm{H}$ & 0.4 & 0.1 & 8,000 \\
\hline I & 0.8 & 0.1 & 3,000 \\
\hline $\mathrm{J}$ & 0.9 & 0.1 & 15,000 \\
\hline
\end{tabular}

To determine the hazard classification, you apply the formula as follows:

$$
\begin{aligned}
\frac{H}{\mathrm{C}} & =\frac{100 \times 2000}{0.3}+\frac{100 \times 4000}{0.6}+\frac{100 \times 3000}{0.8} \\
& +\frac{10 \times 10,000}{7.5}+\frac{10 \times 5100}{8.0}+\frac{10 \times 7500}{9.0} \\
& +\frac{0.1 \times 5000}{0.1}+\frac{0.1 \times 8000}{0.4}+\frac{0.1 \times 3000}{0.8}+\frac{0.1 \times 15,000}{0.9} \\
& =1.745 \times 10^{6} \\
H & =\frac{1.745 \times 10^{6}}{3.8 \times 10^{5}}=4.6
\end{aligned}
$$

The hazard class is "moderate."

If an analysis confirms the hazard class (i.e., $H=4.6$ ), then either an SAR must be prepared for this facility or a sufficient quantity of the toxic substances must be removed in order for $H<1$. The facility would then be in the "low" hazard category, and no further safety documentation would be required. 
An evaluation of the previous example shows that, for most facilities, substances with IDLHs over $100 \mathrm{mg} / \mathrm{m}^{3}$ would add only slightly to the hazard class. In most cases, only the bulk quantities would need to be inventoried (e.g., a container having less than a kilogram in an individual laboratory would not need to be included in the inventory). The material with low IDLHs (IDLHs $<100 \mathrm{mg} / \mathrm{m}^{3}$ ), however, would need careful accountability when determining the inventory.

It is good laboratory practice to maintain the hazardous material inventory as low as reasonably achievable (ALARA). However, if necessary, it should be possible to store materials with low IDLHs in larger quantities, as long as the storage location is protected with appropriate safeguards. 


\section{PROCEDURE WHERE NO IDLH LIMITS HAVE BEEN ESTABLISHED}

If an IDLH Timit has not been determined for a given chemical, the threshold limit value (TLV) or time-weighted average value, as determined by the American Conference of Governmental Industrial Hygienists, is used to calculate the hazard class for nonnuclear chemical hazards at PNL.

When neither of the IDLH or TLV limits exist for a specific chemical, the Industrial Health and Safety Section of Laboratory Safety should be contacted. Industrial Health and Safety then forwards a request to establish interin exposure guidelines through the Toxic Material Advisory Program, which is supported by a DOE contract with the Brookhaven National Laboratory's, Center for Assessment of Chemical and Physical Hazards. These requests are forwarded through DOE-RL. The interim exposure guideline is then used in place of the IDLH value for the purpose of hazard classification. 


\section{CONCLUSION}

Line management at PNL, with the assistance of the Laboratory Safety staff, uses this hazard classification method to determine the hazard class pertaining to their facility. Facilities that are in the "low" hazard class need no further documented safety evaluation for nonnuclear toxic materials. In some instances, low IDLH materiais may be removed from a facility and, as a result, the facility may qualify for the "low" hazard class. However, following an analysis, if the factlity is in the "moderate" or "high" hazard class, an SAR is required. 


\section{REFERENCES}

Atomics International, 1970 LMFBR Safety Programs, Quarterly Technical Progress Reports, January-March. AI-AEC-12947, National Technical Information Service, Springfield, Virginia. (These reports were prepared for the U.S. Atomic Energy Commission.)

Backman, G. E. et a1. 1981. General Safety Assessment Document for PNL-Managed Nonreactor Nuclear Facilities. PNL-3280, Pacific Northwest Laboratory, Richland, Washington.

Mackison, F.W., R.S. Stricoff, L.J. Partridge, Jr., eds. 1978. NIOSH/OSHA Pocket Guide To Chemical Hazards. DHEW (NIOSH) Publication No. 78-210, U.S. Government Printing Office, Washington, D.C.

Mishima, J., and L. C. Schwendiman. 1972. Airborne Release of Plutonium and Its Compounds During Overheating Incidents. BNWL-1651, Pacific Northwest Laboratory, Richland, Washington.

U. S. Department of Energy (DOE). 1979. "Safety Analysis and Review System." In DOE Order 5481.1A, Chapter II. Washington, D.C.

U. S. Energy Research and Development Administration (ERDA). 1975. Final Environmental Statement: Waste Management Operations, Hanford Reservation, Richland, Washington, Volume 1 and 2. ERDA-1538, National Tecinical Information Service, Springfield, Virginia. 


\section{DISTRIBUTION}

No. of

Copies

OFFSITE

30 DOE Technical Information Center

ONSITE

2 DOE Richland Operations Office

JJ Sutey

DH Smith

44 Pacific Northwest Laboratory

GE Backman (12)

JR Berry

$\mathrm{PH}$ Burke

TD Chikalla

JT Denovan

RM Gough

SC Hawley (3)

PM Hickey

RS Hillier

JM Hobbs

KM Jacobsen

RR King

MW Leale

DE Lucas

MA McKinney

NP Nisick

CR Richey

RB Richman

WD Richmond

BD Robertson

ML Rosbach

DJ Sommer

JM Taylor

PA Wright

Publishing Coordination (2)

Technical Information (5) 
